\title{
LE CIEL
}

Le Ciel s'élonge en silence -- pur et lucide, Jamais ému par le nuage ou l'astre;

Il s'accomplit dans la douce perfection -Une création infinie dans un cadre lucide. I1 parle avec les ailes fugitives de mouettes;

Il écoute à travers les chuchotements Dans la brise;

I1 voit à travers un jeune feu éclatant -Le clignotant cyclope -- Ia mer de la vie.

Jerri Sisk

Canyon High School

Canyon, Texas 